\title{
Royal Army Dental Corps to celebrate centenary in 2021
}

\author{
By Lt Col L. Valler RADC, RADC100 Committee Chairman
}

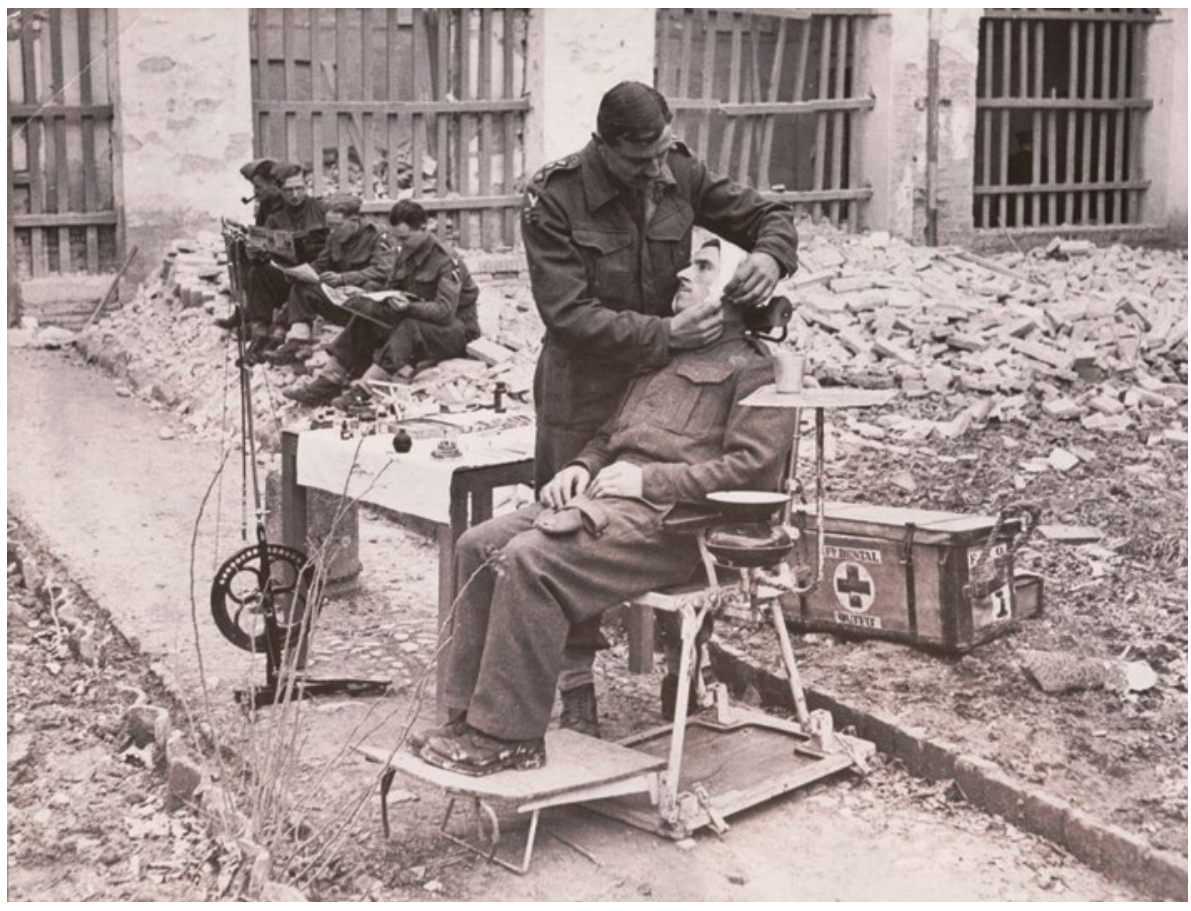

ADC Dental Officer. NW Europe 1944-45 (Courtesy of the Museum of Military Medicine)
In 2021 the Royal Army Dental Corps will be commemorating and celebrating 100 years since its formation in 1921. Over these 100 years the Corps has had an enormously varied history, contributing to the operational effectiveness and health of the Army both in peace and at war.

During the anniversary year we will be organising and taking part in a number of events that will include serving and retired persons from both the Regular and Reserve forces.

Additionally, several members and ex-members of the Corps are writing a series

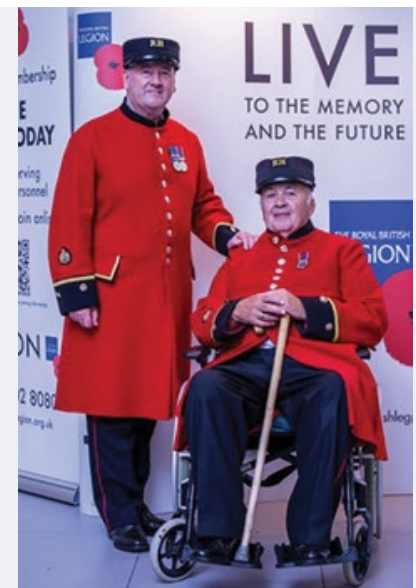

In-Pensioners Craig and Abbott. Formerly RADC soldiers residing at Royal Hospital Chelsea of articles for the British Dental Journal that tell the Corps' story and its contributions to the Army and the wider dental profession. These will appear in a themed issue early in 2021.

The Museum of Military Medicine will be showcasing a temporary exhibition of the history of the RADC and dentistry in the Army. This will be on display at a number of military museums across the UK during the Centenary year.

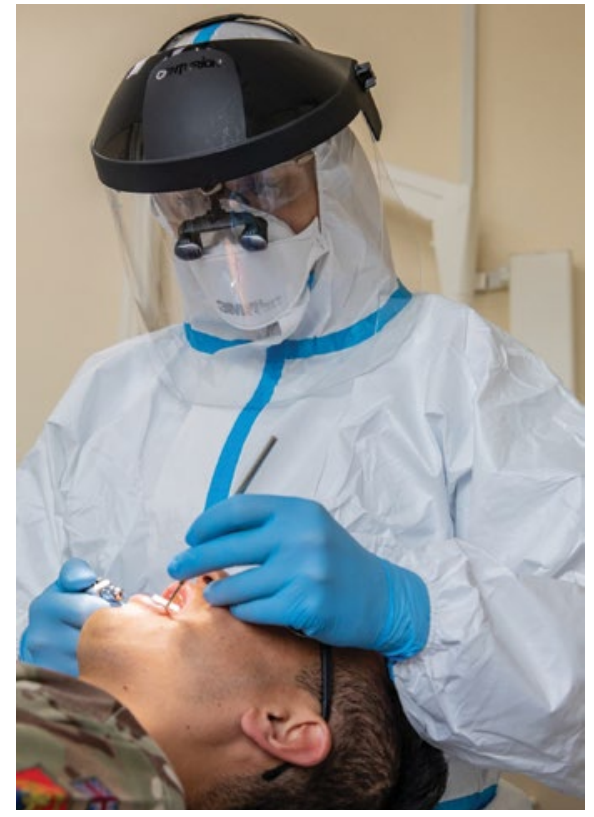

Current RADC Dental Officer working during the COVID-19 pandemic

The success of the Centenary year will depend on ensuring as many people who have been involved with the Corps' history as possible are aware of the plans for 2021 so they can attend the events listed in Box 1. If you are in contact with anyone who might wish to attend any of the above events then please pass on the details.

For more details and updates see http:// www.radc-association.co.uk/ and the Royal Army Dental Corps Facebook site: https://m. facebook.com/groups/2545156595.
Box 1 RADC100 events list for 2021

Dates and full details can be found at http://www.radc-association.co.uk/. Please note all events and dates are subject to revision due to COVID-19 impact.

Centenary Church Service, Aldershot

Centenary CDO(A) Study Day, Donald Taylor Memorial Lecture and Regimental Guest Night

The Corps has commissioned a commemorative stone that will be unveiled at the National Memorial Arboretum. Poppies will be laid by volunteers at the graves of all 55 ADC and RADC personnel who died in the service of their country, and are buried in 49 UK locations.

Ex Northern Pyrenees Dragon, an arduous Level 3 AT exercise, held in the PYRENEES.

Officers' Mess Ball will be held at the Honourable Artillery Club, London.

RADC Warrant Officers and Sgts' Mess Past \& Present Centenary Event, Holiday Inn Farnborough.

Corps Event September 2021 will include a Centenary All Ranks Function with invites to all who have associations with the Corps.

Field of Remembrance at St Margaret's Churchyard, Westminster Abbey on Thursday 11 November. Festival of Remembrance Service at the Royal Albert Hall on the evening of Saturday 13 November. The Corps will be represented by ten serving personnel in the Army contingent for the Muster and Service of Remembrance. Remembrance Sunday will fall on 14 November 2021. As usual there will be a contingent of RADC Veterans taking part in the march past. 